\title{
A CONSTRUÇÃO DE IDENTIDADES ÉTNICO-RACIAL EM EVENTOS DE LETRAMENTO NUMA ESCOLA PÚBLICA municipal de Sáo Paulo
}

\author{
LA CONSTRUCCIÓN DE IDENTIDADES ÉTNICO-RACIALES EN EVENTOS DE LITERACIDAD \\ en una escuela municipal de São Paulo
}

Building Ethnic Racial Identities in Literacy Events at a Municipal School in São Paulo

\section{Claudia Lemos Vóvio}

Doutora em Linguística Aplicada, Universidade Estadual de Campinas, Brasil. Professora Associada do Departamento de Educação, Programa de Pós-Graduação em Educação e Saúde na Infância e Adolescência e Programa de Pós-Graduação em Educação da Universidade Federal de São Paulo (UNIFESP), Brasil. Rua Marco Aurélio, 302, Vila Romana, São Paulo, São Paulo, Brasil. CEP 05048-000

claudiavovio@gmail.com

https://orcid.

org/0000-0002-6141-8203

\section{Estevão Armada Firmino}

Mestre em Educação, Universidade Federal de São Paulo (UNIFESP).

Doutorando do Programa de PósGraduação em Educação e Saúde na Infância e Adolescência, Universidade Federal de São Paulo (UNIFESP).

Rua dos Pássaros, 103, Mooca, São Paulo, São Paulo, Brasil, CEP 03168-020

estevão.armada@yahoo.com.br https://orcid.

org/000-0001-6603-5992

\begin{abstract}
RESUMO
Este artigo aborda eventos de letramento que tematizam a Educação para as Relações Étnicos Raciais, situados na Sala de Leitura, de uma escola pública de ensino fundamental do município de São Paulo (Brasil). Tem como objetivo focalizar a mediação de processos de construção de identidades, em especial àquela que diz respeito à condição étnico-racial dos/as alunos/as, por meio da análise da dinâmica discursiva e dos elementos que constituem tais eventos. Tratase de um estudo qualitativo cujo corpus é constituído por aulas, das quais foram selecionados três eventos, com a participação do professor e de seus/suas alunos/as dos anos iniciais do Ensino Fundamental. Os resultados indicam que esses eventos contribuíram para desestigmatizar e rever estereótipos frente ao continente africano e aos/às negros/as africanos/as e brasileiros/as, produzir novos posicionamentos frente a essas construções sociais e observar os modos como aprendemos a ser o que somos no interior da escola.
\end{abstract}

Palavras chave: identidade; educação étnico-racial; sala de leitura; eventos de letramento.

\section{RESUMEN}

Este artículo se focaliza en acontecimientos de alfabetización con temática de educación para las relaciones étnico-raciales, situados en la sala de lectura de una escuela pública de enseñanza fundamental de un municipio de São Paulo (Brasil). El objetivo es focalizar la mediación de procesos de construcción de identidad en especial aquellas que habla de respeto a condiciones étnico-racial de los alumnos, por medio del análisis de dinámicas discursivas y de los elementos que constituyen tales eventos. Se trata de un estudio cualitativo, cuyo corpus es construido por aulas, de las cuales fueron seleccionados tres acontecimientos, dos de ellos toma parte el profesor y sus alumnos. Los resultados que estos acontecimientos favorecen en desestimar y revertir estereotipos frente al continente africano, los negros africanos y brasileros, donde se producen nuevos significados y su posición 
frente a esas construcciones sociales, observando los modos como se aprende a ser al interior de la escuela.

Palabras clave: identidad; educación étnico-racial; sala de lectura; acontecimientos de alfabetización.

\section{Abstract}

This article covers literacy events in Education towards Ethnical Racial Relations, situated in the Reading Room of a public school of the Fundamental Level in São Paulo, Brazil. The object is to focus on the mediation of processes of construction of identities, specially that which relates to the ethnical racial condition of students, by means of the analysis of discursive dynamics and the elements which constitute these events. It is a qualitative study made up of classes in that three events were selected involving the participation of the teacher and his students between 9 and 10 years of age. The results suggest that these events contributed to destigmatize and review stereotypes as far as both the African Continent and black Africans and Brazilians go, as well as to produce new meanings and facing these social constructs, observing the ways we learn to be what we are within the school environment.

Keywords: identity; ethnic racial education; reading room; literacy events. 


\section{Introdução}

A partir do século XXI, no Brasil, passam a vigorar a Lei 10.639/2003 (Brasil, 2003), que estabelece a obrigatoriedade do ensino da história e cultura afrobrasileiras e africanas nas escolas públicas e privadas de Educação Básica ${ }^{1}$; o Parecer do Conselho Nacional de Educação 03/2004 (Brasil, 2004a), que aprovou as Diretrizes Curriculares Nacionais para Educação das Relações Étnico-Raciais e para o ensino de história e cultura afrobrasileira e africanas (Brasil, 2004b); e a Resolução do Conselho Nacional de Educação (CNE/CP 01/2004), que detalha os direitos e obrigações dos entes federados ante a implementação da lei (Brasil, 2004b). Esses dispositivos legais e prescrições curriculares decorrem da reivindicação do Movimento Negro $^{2}$, de organismos da sociedade civil, de pesquisadores, educadores comprometidos com a luta antirracista e a afirmação da diversidade cultural no Brasil e tornaram-se pontos centrais no processo de implementação de políticas de ações afirmativas na educação brasileira nos seus diferentes níveis, etapas e modalidades educacionais (Gomes e Jesus, 2013, p. 21)

Apesar da intensa produção de parâmetros, planos de ação, documentos curriculares, programas de formação docente, livros didáticos, obras literárias e paradidáticas etc., visando impulsionar mudanças significativas na educação escolar brasileira, esse processo de implementação tem se dado de modo

1 A educação escolar no Brasil é composta por dois níveis: a Educação Básica e o Ensino Superior. A Educação Básica é composta por três etapas, a Educação Infantil, o Ensino Fundamental e o Ensino Médio e é uma atribuição compulsória dos Estados, do Distrito Federal e dos Municípios.

2 Segundo Gomes (2012, p. 22), no contexto reivindicatório que marca o processo de redemocratização no Brasil, o Movimento Negro foi o principal protagonista no sentido de "dar visibilidade ao racismo e sua dinâmica de apagamento no conjunto da sociedade, ao mito da democracia racial, demandando a implicação do Estado para a efetivação da paridade de direitos sociais". tenso $^{3}$. Pois tais dispositivos e prescrições entram em confronto direto "com o imaginário e as práticas de racismo extremamente arraigados na escolarização e no imaginário dos profissionais da educação" (Gomes, 2012, p. 24), sustentados pela dinâmica peculiar com que o racismo se estabeleceu no país,

[...] alicerçado em uma constante contradição. A sociedade brasileira sempre negou insistentemente a existência do racismo e do preconceito racial, mas, no entanto, as pesquisas atestam que, no cotidiano, nas relações de gênero, no mercado de trabalho, na educação básica e na universidade os negros ainda são discriminados e vivem uma situação de profunda desigualdade racial quando comparados com outros segmentos étnico-raciais do país. (Gomes, 2005, p. 42)

Nesse sentido, práticas pedagógicas que possibilitam a reflexão sobre o mundo social e sobre representações hegemônicas e que desnaturalizam fenômenos de ordem social, como o racismo, o mito da democracia racial, as desigualdades sociais e seus mecanismos, tornam-se extremamente potentes na escolarização. Afinal, mais da metade da população brasileira (205,5 milhões) autodeclara-se pretos $(8,2 \%)$ e pardos $(46,7 \%)$ (IBGE, 2016), um incremento de $14,9 \%$ em menos de uma década. Um dos fatores explicativos para essa mudança de ordem sócio-demográfica diz respeito ao reconhecimento dos/as brasileiros/as sobre sua condição étnico-racial, à possibilidade de afirmação de suas identidades como negros/ as e ao estabelecimento do sentido de pertencimento com esse grupo. Esse processo abrange não somente a dimensão subjetiva da construção de identidades, mas refere-se também a uma dimensão política, num país que "ensina aos negros, desde muito cedo, que para ser aceito é preciso negar-se a si mesmo" (Gomes, 2005, p. 43).

Segundo Gomes e Jesus (2013), com base no balanço nacional sobre práticas pedagógicas na perspectiva da lei $10639 / 2003$, o enraizamento dessa

3 As condições materiais necessárias e a formação dos agentes implementadores, os profissionais da educação, nem sempre são adequadamente planejadas e convergem em relação às metas traçadas. 
legislação no cotidiano escolar, de um lado “[...] têm contribuído para legitimar as práticas pedagógicas antirracistas já existentes", e, de outro, "instiga a construção de novas práticas” (2013, p. 17).

É no bojo da implementação dessa política que três eventos de letramento são focalizados nesse artigo. Desenvolvidos numa escola pública, com alunos/as com idades entre nove e dez anos, da rede municipal de São Paulo ${ }^{4}$, num território identificado como periférico. Selecionados intencionalmente, esses eventos de letramento decorrem de uma sequência de atividades que oportunizaram a participação em práticas de linguagem voltadas tanto à apropriação de conhecimentos sobre as relações históricas e culturais entre o continente africano e o Brasil, quanto à formação de atitudes e valores frente à diversidade étnico-racial. Esses eventos evidenciam que os/as alunos/as co-constroem significados com vistas a ação no contexto e no mudo social mais amplo (Moita-Lopes, 2002), apropriam-se de discursos e reacentuam temas tratados na interação.

Com o objetivo de dar a conhecer a pesquisa, apresentamos a seguir as bases teóricas que nos orientaram, a metodologia, o contexto, o corpus, os procedimentos de análise adotados e os resultados observados. Finalizamos com algumas considerações, retomando o papel da escola e dos professores na apropriação de discursos e no agenciamento de identidades sociais.

\section{Letramentos escolares e a construção da identidade social}

O quadro teórico-metodológico mobilizado neste artigo corresponde aos Estudos do Letramento de vertente sócio-histórica e etnográfica: “[...]

4 A Secretaria Municipal de Educação de São Paulo mantém o Núcleo Étnico Racial integrado à Coordenadoria Pedagógica responsável, desde 2005, por implementar as Diretrizes da área por meio da formação continuada, da aquisição e distribuição de materiais didáticos e acervos de obras literárias e filmografia, da produção de documentos curriculares voltados à Educação Étnico-Racial. metodológica e teoricamente sensível à variação local das práticas letradas e capaz de abranger os usos e significados que as próprias pessoas atribuem à leitura e à escrita" (Street; 2014, p. 159). Nessa perspectiva, segundo Viana e colaboradores (2016, p. 29) “[...] as práticas de uso da escrita são consideradas práticas sociais plurais e heterogêneas, vinculadas às estruturas de poder das sociedades", depreende-se que sociedades e os diversos grupos sociais que as compõem, em tempos e espaços específicos, apresentam diversas formas de letramento, tendo a escrita variados efeitos sociais e individuais, em contextos socioculturais específicos. Os letramentos constituem-se em um conjunto amplo de práticas discursivas que podem ser alcançadas em eventos nos quais a escrita é fundamental para o curso das interações e são:

[...] modeladas por instituições sociais e por relações de poder, e algumas são mais dominantes, visíveis e influentes que outras.[...] têm propósitos bem definidos e estão relacionadas a metas sociais e práticas culturais mais amplas. [...] mudam, e novas práticas são frequentemente adquiridas por meio de processos informais de aprendizagem e estabelecimento de sentido. (Barton e Hamilton, 2004, p. 113, tradução nossa)

As pesquisas a partir dessa vertente têm colaborado para a revisão do papel da linguagem escrita nas sociedades e para a atualização dos sentidos atribuídos às práticas de letramento, incluindo aquelas que se instanciam no processo de escolarização. Refere-se à uma escolha de ordem ética e política, que:

\section{[...] traz à tona a plasticidade dos objetos de estudo com os quais lidamos, colocando em questão não ape- nas as próprias teorias que têm ainda predominado no campo dos estudos da linguagem, como também os va- lores que promovem e os efetivos impactos sociais que alcançam ou podem alcançar. (Matêncio, 2009, p. 6)}

Tal perspectiva é tomada como fundamental para compreender o que ocorre na esfera escolar quanto aos usos sociais da escrita diante de sua finalidade educacional e a partir do que essas práticas significam para o conjunto de participantes dessa esfera (Street, 2014; Bunzen, 2010; Macedo, 2005; Street e Street, 2004; Kleiman, 1995). Durante a escolarização básica, professores/as e alunos/as são 
convocados/as, de inúmeras formas, a tomar parte de práticas de linguagem, tanto aquelas voltadas à socialização de conhecimentos disciplinares, por meio da leitura e da produção de textos orais e escritos, como aquelas voltadas ao processo de ensino e aprendizagem da língua escrita. Nesse sentido, assumimos que a experiência nesta instituição possibilita a participação em "um conjunto de práticas socioculturais, históricas e socialmente valorizadas, que possui uma forte relação com os processos de aprendizagem formal da leitura e da escrita, transmissão de conhecimentos e (re) apropriação de discursos” (Bunzen, 2010, p. 101).

Quanto à natureza dos letramentos escolares, especificamente aqueles que se destinam ao processo de ensino e aprendizagem, há autores que criticam a exclusividade de práticas de letramento dominantes, institucionalizadas, e legitimadas socialmente, em detrimento daquelas autogeradas, locais ou vernaculares, que têm origem na vida cotidiana e constituem as bagagens culturais de alunos e professores (Barton e Hamilton, 2004; Kleiman, 1995; Rojo, 2010; Street, 2014; Street e Street, 2004). A imposição de letramentos dominantes, asseveram, levaria à desconsideração, ao apagamento e à marginalização de práticas e produções culturais construídos em outras bases e esferas sociais pelos/ as alunos/as. Kleiman (1995) e Rojo (2010) denunciam que, com a universalização recente da Educação Básica no Brasil, acarretando a chegada novos grupos que sequer acessavam à escola, a predominância da forma escritural e de certos letramentos acabam por gerar conflitos de ordem cultural e linguística. A fim de superar essa problemática, Rojo (2013), sustentada na perspectiva dos Multiletramentos, propõe a circulação de textos/enunciados, considerando um campo de negociação entre variedades de linguagens e de discursos, de maneira a promover a interação com línguas e linguagens e a criação de sentidos de modo plural. A autora aponta que é necessário a "interação entre o plurilinguismo privilegiado nas interações extraescolares e as formas escriturais presentes na escola”, para que se possa atribuir sentido e ressignificar "as cristalizações letradas" (Rojo, 2013, p. 18).
Sobre as interações e dinâmicas que têm lugar nessa esfera social, Lahire (2004) recupera que “[...] a escola não é um simples lugar de aprendizagem de saberes, mas sim, e, ao mesmo tempo, um lugar de aprendizagem de formas de exercício do poder e de relações com o poder" (p. 59). Como articuladas às finalidades socialmente instituídas, as práticas de letramento escolar se encontram ancoradas em legislações, normas, regras e parâmetros, incluindo a seleção sobre o que deve ser objeto de ensino na escola, os modos e tempos do processo de aprendizagem, elementos que atuam para homogeneização dos aprendizados. Durante grande parte de sua história, a educação escolar tem desempenhado o "papel de agenciar a relação entre culturas com poder desigual [...], contribuindo para a manutenção e difusão de saberes mais fortes contra formas culturais que eram consideradas como limitadas, infantis, erradas, supersticiosas" (Fleuri, 2003, p. 23). É preciso ter em mente que o sistema escolar dispõe dos meios para formar gostos e impor seus veredictos e julgamentos, pois é alicerçado em uma hierarquia das relações sociais e dos conhecimentos, em valores fundados na diferença, seja nos níveis e progressão que o organizam, seja nas oportunidades de formação oferecidas (Lahire, 2017).

Se, por um lado, não se pode apagar os problemas decorrentes da hierarquização e imposição dos letramentos na escola, de outro, não se pode tomar seus processos como mero fenômeno de aculturação. Cuche (2002), no campo da Antropologia, admite que as culturas dos diferentes grupos sociais se encontram em maior ou menor posição de força em relação a outras, devendo ser compreendidas a partir dos conflitos e tensões que as constituem e dos quais resultam. Reconhecer que as práticas de letramento escolar são atravessadas, em maior ou menor grau, por conflitos e lutas sociais não deve reduzir suas interpretações de modo determinista, supondo "que o mais forte está sempre em condições de impor pura e simplesmente sua ordem (cultural) ao mais fraco" (Cuche, 2002, p. 145). Além disso, a escola, como espaço-tempo co-construído a partir das relações sociais entre atores, abre-se para "transgressões 
e acordos" (Bunzen, 2010, p. 104), para atos de resistência, entre outros ${ }^{5}$. E, como tal, é produzida com e pelos participantes "nas e pelas interações cotidianas", localmente situadas, autogeradas pela comunidade escolar, mas não deslocadas do contexto sócio-histórico mais amplo.

Retomando as contribuições do Círculo de Bakhtin, os participantes da interação são vistos como posicionados, ocupando lugares e papéis, por meio de seus discursos, e essas posições encontram-se inevitavelmente perpassadas por traços identitários. Seus posicionamentos são surpreendidos em seus enunciados, que correspondem à apreciação valorativa com a qual se alinham em relação a outras que se colocam no horizonte social e temporal (Volochinov, 2017; Bakhtin, [1975]1993). Os sistemas de significação cultural são repositórios de vozes sociais disponíveis em determinados tempos e espaços sociais, que, ao mesmo tempo, se mostram como organizadoras e influentes na construção de sentidos e na formação de novas vozes, por grupos socialmente organizados. Colaboram para situar, na cadeia da comunicação social, as tendências observadas e os alinhamentos preferenciais dos participantes aos modos de designar, de dizerem de si e construírem sentidos para suas experiências. Ao se apropriarem de significados estáveis e colocá-los a favor da interação, os participantes atualizam, refutam ou reacentuam-nos em seus enunciados, em função da identidade dos interlocutores e do contexto mais imediato, da finalidade da enunciação, sem, no entanto, descolar-se do momento histórico e social em que se encontram. Os discursos dos participantes individualizam-se à medida que eles os impregnam com suas intenções e pontos de vista e interagem com os discursos alheios sobre o mesmo objeto, num processo de apropriação no

5 Sobre atores, pertencentes a grupos minoritarizados que empregam táticas e práticas de resistência e de reexistência, constituindo novos letramentos e infiltrando-os em diferentes esferas sociais, ver Souza (2009), Sito (2010, 2016), Kleiman e Sito (2016). qual submetem a linguagem às próprias intenções e acentos (Bakhtin 1993).

Pressupomos que as práticas de letramento que têm lugar na esfera escolar têm o potencial para reafirmar (ou não), reconhecer ou produzir conflitos sobre identidades ${ }^{6}$. Nesse sentido, promover o confronto com uma multiplicidade de identidades com as quais os participantes podem se identificar ou não, pelo menos temporariamente, em eventos de letramento escolar, pode ser útil na concretização de uma Educação para as Relações Étnico-Raciais. Essas situações orientam-se para a construção de sociabilidades e para a socialização de conhecimentos e de modos de ação no mundo, e, por isso, são consideradas como lócus privilegiado para a aprendizagem de quem somos, a exposição à diferença e a tomada de consciência sobre as identidades (Kleiman, 1998; Moita-Lopes, 2002, 2013). Acredita-se que a produção de identidades positivas de negros e negras, mesmo que circunstancial e instável, à mercê das injunções próprias da dinâmica discursiva ${ }^{7} \mathrm{em}$ curso na aula, possa influir para desestigmatizar parcelas representativas da população brasileira cujas identidades e produções culturais têm sido constantemente negadas e depreciadas.

\section{Metodologia, corpus e procedimentos de análise}

A adoção de uma perspectiva sócio-histórico e etnográfica dos letramentos traz implicações para os procedimentos de pesquisa relativos à geração de dados e à análise (Vóvio e Souza, 2005). Trata-se de um estudo de caráter qualitativo e

6 As identidades compreendidas como discursivamente constituídas e produzidas nas interações sociais, conectam-se à diversidade de transações sociais pelas quais os sujeitos passam, produzindo-as a partir e na circulação por variadas esferas sociais, nas posições que podem ocupar nessas circunstâncias e nos usos e apropriação de bens culturais, como os discursos (Hall, 2000).

7 Cf. Kleiman, 1998; Holland et al., 1998; Moita-Lopes, 2002; Vóvio e De Grande, 2010. 
interpretativista, no qual focalizamos, para além da descrição dos eventos, processos de significação, valores, atitudes, sentimentos e relações sociais que estão em jogo nas interações com e a partir da língua escrita.

A escola participante pertence à rede municipal de ensino e integra o Projeto "Negociação do sentido dos textos em contexto escolar de vulnerabilidade social: da análise de práticas interacionais no desenvolvimento de materiais de formação docente" Está localizada num bairro periférico, na região Leste do município de São Paulo, na Subprefeitura de Sapopemba. Essa adesão ao Projeto deu-se de modo cooperativo e voluntário por parte da comunidade escolar. Essa estreita parceria não é gratuita, decorre do processo de formação contínua em andamento que une a equipe de coordenação, equipe docente e a Profa. Dra. Claudia Lemos Vóvio (Unifesp), no qual são aportados subsídios teórico-metodológicos para o ensino de Língua Portuguesa, analisados o currículo da escola e as propostas pedagógicas e, posteriormente, tecidas reflexões sobre os resultados de sua aplicação, entre outras ações. Esses encontros, unindo Escola Pública e Universidade, visam à mobilização de saberes que fomentem a apropriação dos objetos de ensino pelos professores, a compreensão das possibilidades e limites das situações de ensino que empreendem, a intervenção e a proposição de novos modos de ação. Esse movimento funda-se no estudo e no diálogo, bem como numa escuta sensível às problemáticas que colocam em xeque modelos de ação didática adotados por esses profissionais.

8 Trata-se de um estudo que focaliza as aprendizagens em contexto escolar, na França e no Brasil, visando, de um lado, a análise da negociação de sentidos entre professor e alunos em interação didática, focalizando o agir docente, e, de outro, a elaboração de subsídios para a formação inicial de licenciandos que atuarão no ensino de língua materna e língua estrangeira em contextos interculturais. O projeto inclui pesquisadores e alunos de pós-graduação de instituições francesas e brasileiras, USP, UNIFESP e Université Sorbonne Nouvelle.
Do ponto de vista socioeconômico, a localidade onde se encontra a escola é heterogênea, agregando regiões com média, média/alta e alta vulnerabilidade social como descrito pela Fundação Seade (2018), sendo predominantemente residencial, com a implementação de muitos conjuntos habitacionais. A localidade conta com poucos equipamentos de lazer e cultural para o conjunto de seus habitantes. Devido ao seu porte, atendimento, infraestrutura, recursos humanos e materiais disponíveis, é classificada no nível 3 do Indicador de Complexidade de Gestão, numa escala onde 6 é o nível mais elevado9 (INEP, 2015). Em 2017, segundo equipe gestora da escola, contava com 678 alunos: 439 deles matriculados nos anos iniciais e 239 nos anos finais do Ensino Fundamental, distribuídos em turnos, matutino e vespertino. Havia 57 funcionários, entre docentes, gestores, agentes escolares, secretários, etc.

Com relação ao prédio e à infraestrutura, trata-se de uma construção recente, entregue à população em 2009. Possui dois pavimentos e área externa com estacionamento, pátios e quadra esportiva coberta. Familiares e visitantes acessam a escola por meio de uma pequena janela instalada na secretaria ou pelos portões no momento de entrada e saída. A partir da entrada de funcionários, tem-se acesso ao corredor do pavimento térreo que leva à secretaria, sala de direção, a nove salas de aula, quatro delas destinadas ao primeiro ano da alfabetização. Nas paredes dos corredores, há murais com trabalhos dos estudantes e exposições. Há pouca circulação, durante o momento de aulas nesse corredor. Do lado direito, logo após a portaria, encontram-se

9 Segundo nota técnica do INEP, o Indicador de Nível Socioeconômico das Escolas é uma medida cujo objetivo é situar o conjunto dos alunos atendidos por cada escola em um estrato, definido pela posse de bens domésticos, renda e contratação de serviços pela família dos alunos e pelo nível de escolaridade de seus pais. A medida de nível socioeconômico dos alunos é calculada com os dados da Prova Brasil e da ANEB de 2011 e 2013, bem como os dados do ENEM de 2011 e 2013 e compreende sete estratos: partindo de Muito Baixo até Muito Alto. 
as escadas que levam ao pavimento superior que dá acesso à sala de coordenação, sala e refeitório de professores e 10 salas de aulas dos ciclos interdisciplinar e autoral. Nas paredes, tanto dos lances de escada quanto as do corredor também estão expostos trabalhos e textos dos estudantes. Ao final do corredor, um pouco isoladas do conjunto, um pequeno lance de escada e rampa dão acesso à Sala de Leitura, com acervo de literatura e de paradidáticos, e à Sala de Informática, com 21 computadores em bom estado e on-line para uso de alunos e professores. As salas de aula dos anos finais do Ensino Fundamental têm uma organização diferenciada, cada uma correspondendo a um componente curricular, denominadas salas ambientes, acessadas pelos estudantes de acordo com o quadro de aulas. Esse é um corredor mais movimentado, mas a troca de salas pelos alunos parece orquestrada, pois dificilmente há estudantes circulando ou barulho.

Os professores contam com um arsenal diversificado de instrumentos e equipamentos para as aulas, tais como: aparelho de DVD, projetor multimídia, televisores e copiadora, além de alguns jogos pedagógicos, materiais escolares, livros didáticos e técnicos, para estudo. No entanto, são pouco utilizados, segundo a percepção da coordenação.

Quanto ao perfil dos estudantes, segundo os dados da Prova Brasil, sistematizados pelo INEP (2015), mais da metade (55\%) dos estudantes caracteriza-se como do sexo masculino, autodeclarando-se majoritariamente como de cor preta ou parda (um terço e um quarto, respectivamente) com nível socioeconômico calculado em médio/ alto (comum aos estudantes de escolas públicas da região metropolitana de São Paulo). No entanto, o convívio na escola aponta para certa heterogeneidade nesse conjunto, com a presença de grupos de alunos em condições de maior vulnerabilidade socioeconômica.

O corpus foi gerado a partir de gravações em áudio e vídeo de quatro aulas (três com duração de 45 minutos e uma com 75 minutos), de notas de campo e do planejamento das atividades pelo professor $^{10}$. Essas aulas ocorreram na Sala de Leitura ${ }^{11}$, sob a gestão do professor orientador da sala de leitura (doravante POSL) e seus/suas 18 alunos/as do quarto ano do Ensino Fundamental. As aulas articulavam-se ao Projeto Diversidade Étnica estabelecido no Plano Anual de Ação (PAA) ${ }^{12}$ desta escola. A sequência de atividades ${ }^{13}$ visava à apropriação de conhecimentos históricos, geográficos e culturais do continente africano e abordava as relações entre esse continente e o Brasil, bem como à formação de atitudes e valores frente à diversidade étnico-racial própria ao conjunto de atores dessa escola, focalizando a compreensão e a ampliação do direito à diferença.

As aulas da Sala de Leitura organizam-se de modo diferente, com ocorrência semanal e duração de 45 minutos $^{14}$, promovem a participação em práticas de leitura variadas, integram, na atualidade, a grade curricular das escolas municipais de Ensino

10 A equipe de gestão, professor, familiares e responsáveis, e os/as alunos/as autorizaram/aceitaram participar da geração de dados, conforme Termo de Autorização e Consentimento Livre e Esclarecido, após a apresentação dos objetivos da pesquisa.

11 Programa implementado na Rede Municipal de Ensino de São Paulo, desde os anos de 1970, que instituiu um espaço e tempo específico para o acesso ao livro e a mediação de leitura, destacando um docente responsável pelo planejamento e condução de aulas (São Paulo, 2018). Consultar Polido-Silva (2012) e Firmino (2015).

12 O Plano Anual de Ação da escola prescrevia para o conjunto da escola a concretização de um trabalho interdisciplinar de ensino e aprendizagem, com o objetivo de: "[...] articular as áreas de conhecimento com as temáticas vivenciadas na sociedade e promover reflexão, discussão e análise dos temas urgentes para a vida cidadã consciente e atuante [...]", que culminou em uma atividade dirigida a toda comunidade escolar, designada por "Sarau da escola" (mimeo).

13 O planejamento dessas atividades deu-se de modo colaborativo, envolvendo além do POSL, os pesquisadores do Projeto "Negociação do sentido dos textos em contexto escolar de vulnerabilidade social: da análise de práticas interacionais no desenvolvimento de materiais de formação docente".

14 A instância prescritiva mais direta sobre o trabalho do POSL é a "Portaria N. ${ }^{\circ}$ 7655/15" (São Paulo, 2015). 
Fundamental de São Paulo. No âmbito da escola campo, especificamente, a Sala de Leitura configura-se como:

[...] (i) um espaço marcado pela existência de um acervo, (ii) uma intenção institucional de ali ser um espaço destinado à leitura, (iii) sua utilização por alunos que trazem inúmeras trajetórias de acesso às culturas escritas, e (iiii) um posL que traz também suas concepções de leitura e de leitor. (Firmino, 2015, p. 187)

Conforme Firmino (2015), essas aulas são compostas por eventos de letramento diversificados, planejados pelo professor, com finalidades didáticas, e outros infiltrados ou propostos pelos/as alunos/as, nos quais há textos escritos e pessoas realizando atividades em ambientes socialmente construídos, a partir de finalidades compartilhadas, com e a partir de artefatos culturais escritos, demandando aos participantes assumirem certos papéis e mobilizarem recursos de várias ordens.

Desse conjunto, selecionamos três eventos específicos que compóem uma dessas aulas, gravada em 14 de junho de 2017. A análise fundamenta-se na proposição de Hamilton (2000) quanto à descrição dos eventos de letramento, a partir de seus elementos visíveis (ambiente, artefatos, participantes e atividades), bem como de seus elementos não-visíveis (os participantes ocultos, que circunscrevem as interações, a função social e os sentidos das práticas de letramento, assim como valores e recursos acionados pelos participantes na interação e as rotinas estruturadas do contexto que regulam modos de agir). A fim de colocar em evidência a tematização da Educação para as Relações Étnicos Raciais, no âmbito dos eventos de letramento, detivemo-nos também na dinâmica discursiva produzida no interior desses eventos, dando atenção aos enunciados produzidos pelos/as alunos/as e professor, tomadas como facetas dessa dinâmica e, à "[...] relação com a produção de sentido e de sistemas de referências, compreendidas como interpretações possíveis que os grupos humanos organizam do mundo" (Bunzen, 2009, p. 112).

O conceito de letramento escolar adotado abarca, portanto, a dinâmica discursiva das aulas, articulando-a à compreensão do contexto social mais amplo e dos microcontextos de interação. Ainda que o objetivo de nossa análise não seja a interação em sala de aula, tornou-se relevante caracterizá-la de modo geral e abarcar sequências e imagens desses eventos, para situar os modos como os/as alunos/as se posicionam sobre os temas em disputa e reacentuam conhecimentos, sobre os textos e em relação a si e a seus pares.

Os eventos em tela decorrem de duas atividades distribuídas na primeira aula (com 43 minutos de duração), gravada em 14 de junho de 2017, na turma de quarto ano, contando com 18 alunos/as, o POSL e duas pesquisadoras que manejavam a câmera. Como no quadro 01 , o evento de letramento 01 integra 20 minutos e 4 segundos de duração, refere-se à produção de um banco de palavras associadas ao continente africano, que, registradas pelos/as alunos/as, foram lidas e categorizadas coletivamente.

Quadro 1 Atividades da aula e eventos analisados

\begin{tabular}{|c|c|c|c|}
\hline Atividades didáticas & Linha do tempo da aula & $\begin{array}{c}\text { Eventos } \\
\text { analisados }\end{array}$ & $\begin{array}{c}\text { Sequências/ } \\
\text { Figuras analisadas }\end{array}$ \\
\hline Empréstimo e devolução de livros & 00:00:01-00:00:15 & 一 & - \\
\hline Produção de banco de palavras sobre o continente africano & $00: 15: 02-00: 23: 45$ & Evento 1 & Sequência 3; Figura 3 \\
\hline Apreciação de ilustrações em livro de fábulas & 00:23:47-00: 29:53 & - & - \\
\hline Produção de banco de palavras sobre o continente africano & $00: 29: 54-00: 35: 07$ & $\begin{array}{l}\text { Continuação do } \\
\text { Evento } 1\end{array}$ & Sequência 3; Figura 3 \\
\hline Exibição do videoclipe "África" & $00: 35: 40-00: 38: 45$ & Evento 2 & Figura 4 \\
\hline Roda de conversa sobre o conteúdo temático do rap África. & $00: 39: 10-00: 41: 18$ & Evento 3 & Sequências 4, 5 e 6 \\
\hline
\end{tabular}


O evento de letramento 2, com 3 minutos e 5 segundos de duração, diz respeito à recepção do videoclipe do rap África, da rapper MC Soffia, por meio de sua exibição. E o evento de letramento 3, com 11 minutos e 8 segundos de duração, refere-se ao momento de apropriação da canção pelos/ as alunos/as, quando se posicionam sobre o conteúdo temático da canção (Quadro 1).

A escolha desses eventos deveu-se aos discursos produzidos nessas ocasiões e ao seu conteúdo temático, diretamente relacionado ao tema desse artigo, bem como às participações inesperadas $\mathrm{dos} /$ as alunos/as e aos posicionamentos assumidos por eles/as tanto na produção do banco de palavras como na recepção e apropriação da canção.

\section{Eventos de letramento na Sala de Leitura: identidades sociais em construção}

Os eventos em tela foram ambientados em um local que se diferencia de outros espaços escolares e do modo como tradicionalmente se pratica a leitura, em aulas de língua materna (Figura 1). A sala é ampla, abrigando um acervo de cerca de 4 mil livros (a maior parte de obras literárias), com mobiliário específico (mesas coletivas, estantes onde estão dispostos os livros, expositores na altura das crianças e adolescentes, quadros decorativos, quadro branco, tapetes e pufes para acomodar os/as alunos/as) e equipamentos (projetor multimídia, tela de projeção, computador, com acesso à internet, aparelho de som e DVD).
As atividades desenvolveram-se em um círculo na parte central da sala, no qual, ao centro se encontrava um tecido com estampas africanas que recobria dois mapas que seriam utilizados para a localização do continente africano e do Brasil. Durante a aula, diversos eventos de letramento ocorreram, desde aqueles planejados, introduzidos e mediados pelo posL, passando pelos rotineiros, como conversas coletivas sobre textos e empréstimos de obras, até os imprevistos como a apreciação de ilustrações de um dos livros do acervo. A ambientação deu-se em razão das finalidades didáticas e tanto a infraestrutura e o acervo como os processos de mediação colocaram-se a favor da produção escrita e da apropriação de discursos pelos/as alunos/as.

Ora o POSL sentava-se próximo aos/às alunos/ as, ora levantava-se, buscando uma posição para que todos, ao mesmo tempo, escutassem suas explicações, ora conversava com pequenos grupos, atendia a demandas individuais, variando os modos como conduzia a aula. Apesar dos papéis autoevidentes dos participantes que tipificam os eventos de letramento escolar, (o POSL é responsável por gerir eventos com base em seus objetivos didáticos, assumindo as funções de animador, informador e avaliador, os/as alunos/ as aderem e se engajam nas propostas feitas pelo professor), observamos também traços que diferenciam as interações nesses eventos em relação às aulas ditas canônicas. Em relação ao POSL, chama

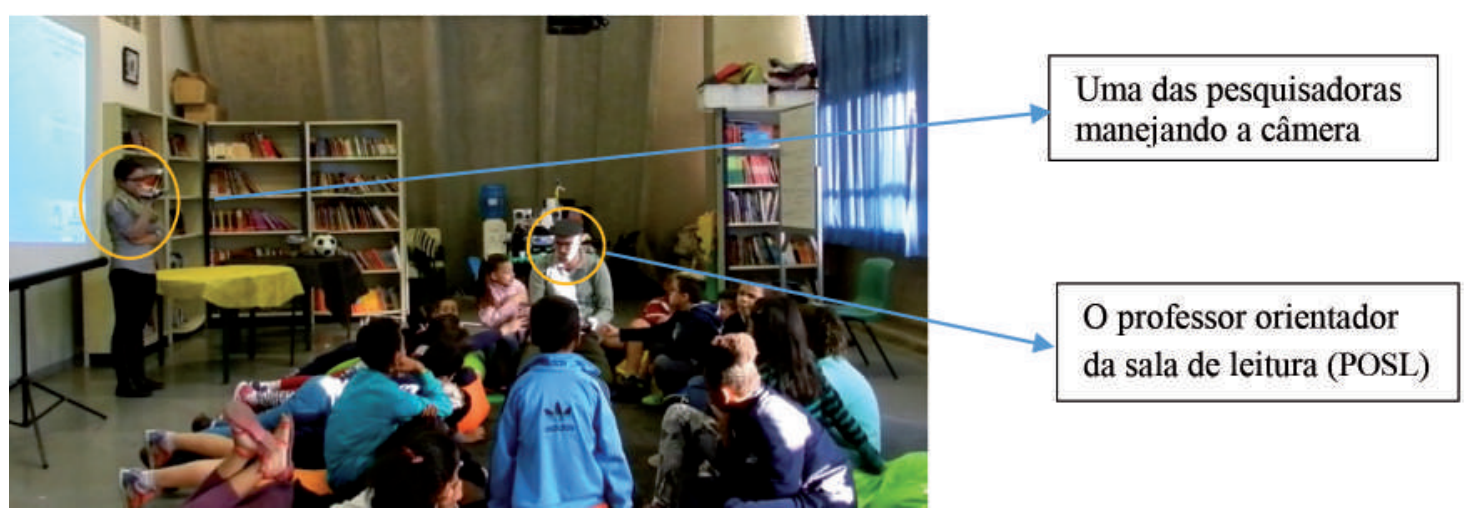

Figura 1 Ambientação da sala 
atenção o comprometimento ético com os/as alunos/as tanto na produção do plano de atividades, designado como projeto didático autoral , como no modo como se relaciona com ele/as. Esses traços evidenciam-se na dinâmica discursiva nesses eventos, especialmente, quando retoma os dizeres dos/as alunos/as (por meio de paráfrases, repetições e reformulações), repondo esses posicionamentos à apreciação de toda a turma, valorizando-os. No excerto a seguir, quando dois alunos preferem oralizar as palavras em vez de grafá-las, como solicitado na produção do banco de palavras sobre o continente africano, o POSL aceita essa participação alternativa e repete seus dizeres para todos, validando-as e avaliando essas participações positivamente.

POSL: ((volta-se para os dois alunos que estão ao seu lado e que não grafaram as palavras na cartela))

agora... oh... falta o Leo e o Cris... que eles não escreveram... eles vão falar... que que veio na sua cabeça ((ao pensar em África)) ... Leandro?

Leo: africano

POSL: africano... a palavra na cabeça dele veio africano ... quando ele pensou em África... que que vem na sua cabeça... Cris?

Cris: escravo

POSL: escravo... boa... primeira parte da aula foi isso...

(Excerto do evento 1, Produção do banco de palavras)

Também se mostram na adesão de proposições da turma, que nem sempre convergem com o planejado. A curiosidade dos alunos em relação às ilustrações de corpos humanos nus e de animais com representações de sua genitália num livro utilizado como suporte para a grafia das palavras contagiou o grupo, causando grande alvoroço por tempo significativo da aula (cerca de seis minutos). Mesmo que a observação dessas ilustrações e a conversa sobre elas não estivessem previstas na aula, o professor abriu espaço para que todos acessassem exemplares do livro, contextualizou a obra e comentou sobre a coletânea de fábulas e ilustrações, propiciando que pudessem observá-las e comentá-las (Figura 2).

Sobre a organização discursiva, quando observamos a distribuição de turnos nos eventos 1 e 3, notamos que os turnos do professor não ultrapassam $50 \%$ do total, evidenciando que, mesmo que com a assimetria típica das aulas, há possibilidades para que os/as alunos/as participem da interação, denotando uma aula mais dialogada do que transmissiva. Para gerir didaticamente esses eventos, o professor implementa, preferencialmente, o par Pergunta-Resposta: as perguntas são lançadas ora para o grupo todo, ora especificamente para algum/a aluno/a. Em poucos casos, o professor verifica a validade dos dizeres dos/as alunos/as e, quando o faz, tece avaliações positivas, já que tais participações são tomadas como oportunidades para levar a aula adiante.

Os/as alunos/as, por sua vez, participam da interação nos termos com que Rampton (2006, p. 30 apud Garcez e Lopes, 2017, p. 66) definiu a nova

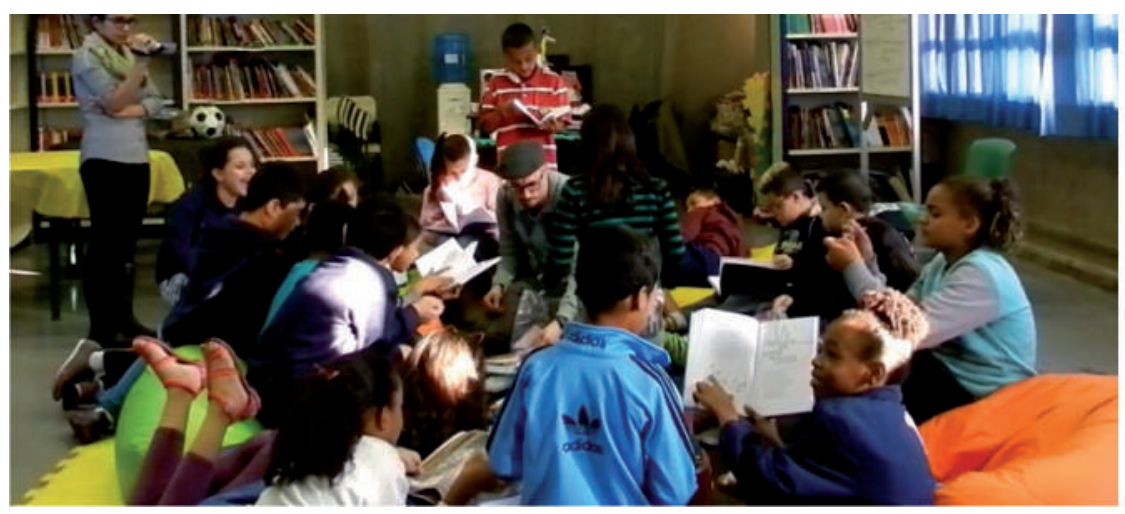

Os livros foram distribuídos para a turma, os/alunos/as folheiam e comentam entre si sobre as imagens.

Figura 2 Apreciação pelos/as alunos/as das ilustrações de um livro de fábula 
ordem comunicativa na sala de aula contemporânea, por meio de "participações exuberantes". A adjetivação exuberante, explicam Garcez e Lopes (2017, pp.66-67), é empregada por Rampton para indicar a "característica vigorosa e performática de interpelação" dos/as alunos/as.

Tais traços evidenciam-se pelo fato de que os/as alunos/as não se limitam a falar somente quando o professor os/as autoriza, para responder às suas iniciações. Eles se autosselecionam: cerca de $30 \%$ dos turnos nos eventos 1 e 3 decorrem da autosseleção por três alunos, Monique, Duda e Ivan.Também e mostram nas respostas às perguntas dançando e cantando (23 ocorrências, no evento 3 ), interrupções para tratar de algo do próprio interesse (1 ocorrência, envolvendo toda a turma, no evento 1), na proposição de questóes ao POSL e demais colegas ( 4 ocorrências, 1 no evento 1 , e 3 no evento 3), na disciplinarização voluntária de colegas ( 1 ocorrência no evento 3 ), nas sugestôes para o tratamento de assuntos (2 ocorrências, uma no evento 1 , e outra no evento 3 ). No exemplo a seguir, no evento 1 , observamos o momento em que Monique disciplina outra colega, que está interrompendo a fala do POSL (dançando e cantando junto aos dizeres do professor e demais colegas):

POSL: oh... TRÊS coisas que vocês... NA verDAde foi... a Monique... a Duda... e o Ivan... a Duda... onde tudo começou... a Monique... princesa/a rainha guerreira que a MC Soffia quer ser igual ... e o Ivan... eh:... do cabelo black e do nariz achatado... três coisas... eu estou com a letra... da música aqui oh... vou ler pra vocês a letra...

Duda: África, onde tudo começou: ((dirige-se ao centro do círculo e canta e dança para o professor)) POSL: [espera aí Duda

Monique: [fica QUIE:ta:

(Excerto do evento 3, durante a conversa sobre a canção)

Focaliza-se a seguir a dinâmica discursiva produzida em cada evento, trazendo sequências que evidenciam os traços de interação descritos e o processo de mediação de identidades que se deu nessas ocasiões.

\section{Evento 1: Quando penso em África}

Nesse evento, os/as alunos/as são convidados/as a grafarem palavras que associavam ao continente africano, numa cartela. Sua finalidade era acessar conhecimentos prévios e representações desses/ as alunos/as sobre esse continente e, além disso, categorizar e comentá-las. Houve grande movimentação dos/as alunos/as e conversas paralelas. Alguns realizaram de imediato a demanda do professor, outros o interpelaram sobre a escrita correta de palavras ou sobre a adequação de suas escolhas, outros, ainda, discutiram sobre o que escrever com seus pares. Outra ocorrência relevante no evento foi sua interrupção por parte dos/as alunos/as. Ao empregarem livros do acervo para apoiar a grafia nas cartelas, depararam-se com uma coletânea de fábulas e ficaram curiosos em relação às ilustrações. Essa interrupção, apesar de longa, não impediu a retomada e continuidade da tarefa pelo professor. Assim que todos entregaram suas cartelas, o POSL leu em voz alta a produção escrita e coletivamente propôs o agrupamento das palavras, adotando o critério de aproximação semântica. Os termos eleitos e grafados pelos/as alunos/as foram: negros (nove ocorrências), animais, animais carnívoros e bichos (seis ocorrências), árvores (cinco ocorrências), escravos (quatro ocorrências), viagem (duas ocorrências), trabalhadores (uma ocorrência) e índios (uma ocorrência).

O professor propôs três conjuntos. Um deles remetia à condição étnico-racial dos/as africanos/as, negros e negras e "índios" (este último, possivelmente relacionado à representação de tribos africanas). Outro, à condição de escravizados e trabalhadores (ligado ao que sabem sobre a história da Diáspora negra e sobre a história do Brasil). E outro associava o continente à natureza: animais, animais carnívoros, bichos e árvores. $\mathrm{O}$ único termo que se destacou foi viagem, talvez relacionado a programas de $\mathrm{TV}$ e documentários que retratam o turismo na África.

Além de representar, em certa medida, as associações que os/as alunos/as fazem em relação à África, 
esse conjunto permite entrever suas visões, que, nesse caso, pautaram-se por significados correntes e socialmente disponíveis. Do ponto de vista da história das civilizações africanas, da Diáspora negra, o que inclui a história do Brasil e do legado cultural africano, o banco parece restrito, o que não destoa de visões estereotipadas, popularizadas e sedimentadas sobre o continente africano, principalmente, em produções culturais de massa como filmes, desenhos animados e reportagens. Nesse sentido, o posicionamento inicial dos/as alunos/as denota um conhecimento parcial da história da África e do Brasil, conteúdo previsto para esta etapa da escolarização em documentos curriculares e legislação educacional brasileira. Outras visões seriam possíveis no caso de experimentarem uma abordagem epistemológica da África na escola, que desconstruísse ou colocasse em conflito visões que se perpetuam na mídia, redimensionando seu estatuto, colocando-a em "pé de igualdade com as demais culturas que contribuíram para a formação do povo brasileiro", e que "rompa com ideias preconceituosas da herança intelectual colonialista”, como propõe Munanga (2008, p. 23).

Ainda no evento 1, no momento em que alunos/ as e POSL categorizaram as palavras, duas alunas colaboraram diretamente com a síntese dos termos que compõe o banco produzido pela turma.

POSL: escravo... boa... primeira parte da aula foi isso... oh Monique... vem pra cá com a gente... o que que a gente pensa sobre África -- o que que a gente acha que tem na África... pessoas negras... africanos... animais... árvores... ótimo... aGO:ra... nós vamos pra segunda... alguém quer falar mais alguma coisa? foi isso...

POSL: Ô Monique vem pra cá com a gente. Que que a gente pensa sobre a África, que a gente acha que tem na Àfrica, pessoas negras, africanos, animais, arvore, ótimo.

Duda: [lindas (...)

POSL: agora, nós vamos para a segunda. Alguém quer falar mais alguma coisa?

Monique: professor ((mostra um livro que está em suas mãos))

POSL: o que que é isso?... oh... peraí... a Monique achou um livro que chama cadernos negros... contos Afro-brasileiros... volume trinta e seis... por que que você me mostrou esse livro... Monique?

Monique: por causa/que que tá falando sobre os negros aí: [...]

Monique e Duda têm atuação destacada nesse momento. Durante a construção da síntese de palavras, Duda enuncia o adjetivo lindas, no momento em que o POSL refere-se a pessoas negras, complementando a expressão, por meio da adjetivação ("lindas"). Como mostra a figura 3, Duda está em posição oposta ao POSL, distanciada da turma e deitada num pufe, o que pode denotar que não estava engajada na interação.

A adjetivação de Duda opera no sentido de acentuar um atributo positivo à expressão pessoas negras. Não se trata apenas de pessoas negras para a menina, mas de pessoas negras e lindas, o que as reposiciona discursiva e identitariamente. Duda, nos eventos seguintes, colaborará na interação de modo relevante, mas, nesse momento, já demonstra uma visão positiva acerca da identidade negra.

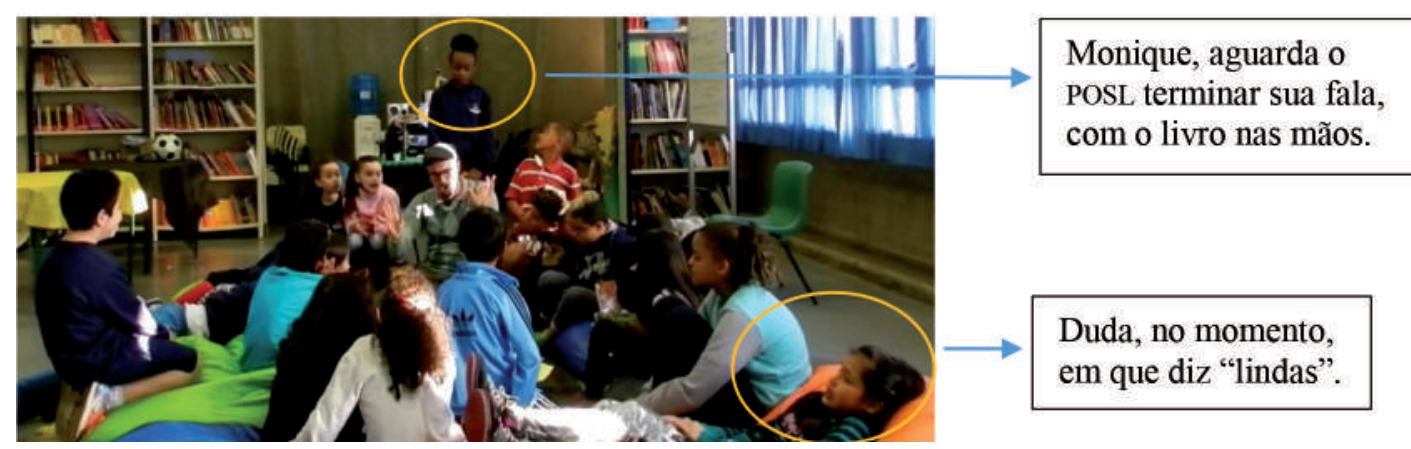

Figura 3 Evento 1 - Síntese do banco de palavras apresentada pelo POSL 
O emprego de um qualificador positivo contrasta com o conjunto restrito de termos produzidos pela turma, ampliando-o. Seu posicionamento não foi percebido pelo POSL ou pelos colegas, sua fala além de sobreposta é enunciada de um lugar mais distante que dos demais (Figura 3), impossibilitando sua apreensão pelo conjunto.

Monique, por sua vez, ao final do evento, quando o POSL finaliza a síntese do banco, apresenta um livro que seleciona das estantes. Não é qualquer livro, ela escolheu o título "Cadernos Negros: contos afro-brasileiros", número 36 , da editora Quilombo Hoje. Essa coleção dedica-se a disseminar a produção literária de afro-brasileiros/as. A capa amarela tem como ilustração o perfil de uma mulher negra, com um turbante com estampas africanas. Essa indicação de Monique ao professor revela seu engajamento com a temática e colabora para ampliar fontes de pesquisa sobre o tema em jogo. Ambas agem no sentido de ampliação da produção coletiva.

\section{Evento 2: África, onde está meu coração}

No evento 2, os/as alunos/as são convidados a assistirem à exibição de um videoclipe. Inicialmente, o POSL contextualiza a recepção, dando indicações sobre o contexto de produção e circulação do gênero e sobre a compositora e intérprete. O videoclipe apresenta o rap "África ", interpretado por uma rapper negra de 14 anos, trata-se de um subgênero da canção, cujo conteúdo temático valoriza a cultura africana e a presença de africanos/as no Brasil, além de relacionar personalidades da história da África e do Brasil. MC Soffia é a figura central do videoclipe, artista que tem ganhado notoriedade pelo teor político e contestatório de suas canções, que tematizam o direito à diferença, o racismo e aspectos $\mathrm{da}$ vida urbana e da infância em periferias, veiculadas em mídias digitais.

Em relação ao videoclipe, concordamos com Mozdzenski (2012, p. 14), que o caracteriza como integrando "um grande número de recursos e estratégias multissemióticos”. Para o autor, a estrutura composicional do videoclipe coloca em relevo a perfomatividade do artista, e, em alguns casos, como nesse videoclipe, focaliza a autoimagem e os atributos da rapper: negra, jovem, com cabelo em estilo black power, com vestes brilhantes e um grande laço no cabelo. Além disso, o videoclipe em questão apresenta um rap, gênero que põe em relevo discursos de denúncia e de contestação e engloba ainda a performance, corporeidade, a sonoridade e a oralidade, entre outros recursos multimodais que se colocam a favor da produção de sentidos.

Após a contextualização do videoclipe (Figura 4), a turma comporta-se como se estivesse em um programa de auditório, ovacionando a cantora, batendo palmas, enunciado seu nome de modo

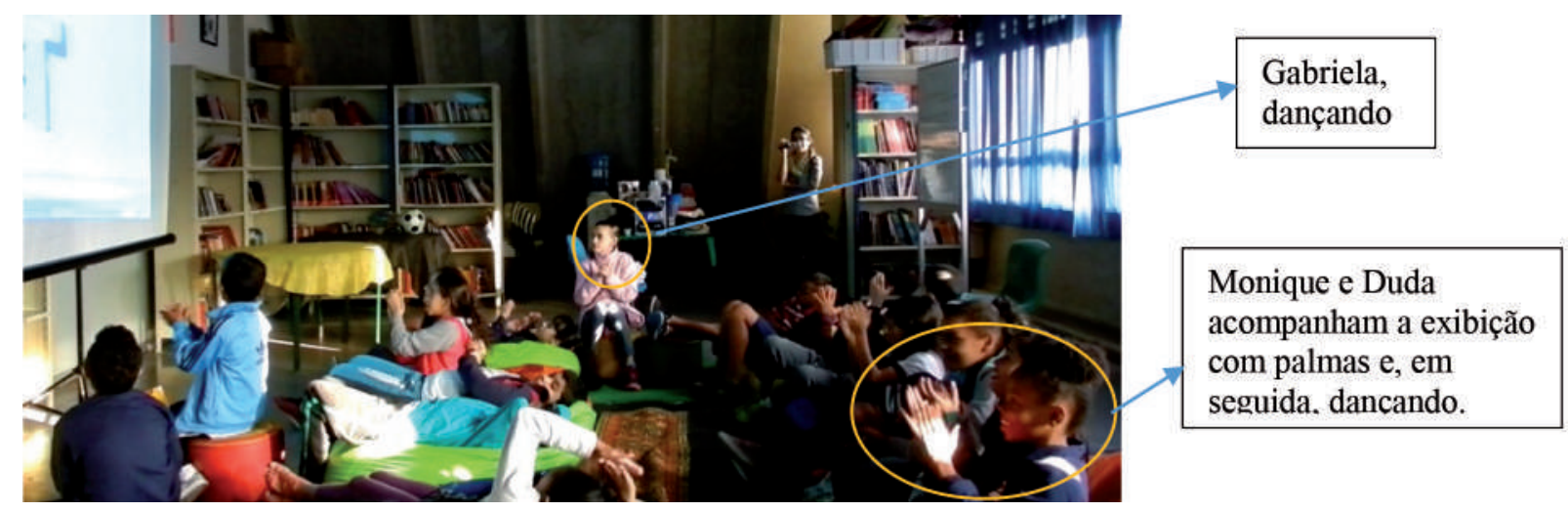

Figura 4 Exibição do videoclipe África 
ritmado, com entusiasmo. Nesse momento, seus conhecimentos prévios (sobre o gênero) e a identificação positiva com a rapper (seu repertório, voz, gestos, corporeidade, estilo etc.) evidenciam-se por meio das palmas e gritos empolgados.

Durante a exibição do videoclipe, reacomodam-se de modo a assistir à projeção. Permanecem por alguns momentos sentados nos pufes e almofadas, mas à medida que o videoclipe se desenvolve, acompanham a canção, com palmas e movimentos corporais ritmados, esboçando conhecimentos sobre a performance corporal que constitui o rap. Monique, Duda e Gabriela iniciam os movimentos e logo são acompanhadas por toda a turma: elas movem-se a partir do ritmo, demonstram habilidades para acompanhar e empregar gestualidade característica dos rappers. Também se apropriam rapidamente do refrão, cantando-o em voz alta. A recepção do rap pela turma distingue-se de uma aula convencional de leitura, na qual os alunos escutam/leem textos silenciosamente, para depois comentá-los ou realizarem tarefas de compreensão. A participação diferenciada dos/ as alunos/as dançando e cantando instancia uma organização não canônica na aula, o que é acolhido pelo professor.

Ao final da exibição, retomando o comportamento comum a um programa de auditório, aplaudem e gritam o nome da cantora de modo ritmado: " $M c$ So::ffi::a Mc So::ffi::a Mc So::ffi::a". Esse modo de recepção traz várias decorrências para o próximo evento (3), no qual é proposto a conversa sobre o conteúdo temático da canção, enfatizando uma das facetas gênero: a letra da canção.

\section{Evento 3: África, onde tudo começou}

Se no evento de letramento 2 a escrita perpassa a interação de modo indireto, no evento 3 será presentificada pelo POSL, por meio do tratamento do conteúdo temático do rap, por meio da implementação do par pergunta-resposta e do recurso à letra da canção impressa. Os/as alunos/as, neste momento, estavam muito agitados, a turma buscava novos espaços e pufes para se acomodar. Em relação à mediação de processos de construção de identidades sociais, três situações merecem atenção: a) a autosseleção dos alunos/as, durante esse evento (Monique, Duda, Ivan e Gustavo) e o modo como o POSL se aproveita dessas participações para atingir seu objetivo didático, b) o modo como Duda responde às perguntas do professor; c) a reacentuação de temas da canção (Duda, Ivan, Monique e Gustavo), reformulando posicionamentos iniciais frente ao continente africano, sobre os/as negros/as e afrobrasileiros/as.

O evento tem início com a pergunta do POSL: "agora...al qual era o tema da música da MC Soffia?”. Duda, Monique e Gabriela respondem dançando e cantando o refrão da canção: "África, onde tudo começou / África, onde está meu coração DJ". Duda empregará este primeiro verso insistentemente em resposta ao professor, comportamento que diverge das expectativas didáticas do docente, pois tenta regular seu comportamento sem êxito, como na sequência abaixo:

POSL: a gente viu os papeizinhos [cartelas com palavras produzidas pelos/as alunos/as], agora a / qual era o tema da música da MC Soffia?

Duda, Monique e Gabriela: Á::frica ((cantando)).

Duda: Á::fri::ca, Á::fri::ca, onde tudo começou:: ((cantando))

Als: Á::frica ... quando tu::do terminou:: ((cantando))

Duda: Á::fri::ca, Á::fri::ca, quando tudo começou:: ...

Á::frica ((cantando e dançando))

Als: [África ((cantando e dançando))

Duda: Vai, agora assim (xxx)

POSL: Que palavras, que palavras, peraí ... Duda você que tá empolgada, que palavras a Mc Soffia

Duda: oi?

POSL: a MC Soffia ... fala, vocês escolheram algumas que veio / vieram na cabeça de vocês, quais foram as palavras que a MC ... calma ... agora, o. Ela fala, a MC, a Duda: [Bom, bom, bom, bom

POSL: Duda ... o peraí só um pouquinho, que palavras, Duda fala aí, duas ou três palavras que a MC Soffia fala da África

Duda: África, onde tudo começou ((cantando e dançando))

A resposta performática não corresponde às expectativas do POSL, que age no sentido de reorganizar 
a conversa sobre a letra do rap. Esse gênero discursivo multimodal emprega outras semioses para além da linguagem verbal na construção de sentidos, o ritmo, a corporeidade, a sonoridade, todos elementos que resultam no tratamento temático e influentes nos processos de significação e apropriação desses discursos. Duda parece produzir suas respostas sustentada no modo como os enunciados se conformam nesse gênero. Além disso, elege um verso do refrão, repetido a cada pergunta ou tentativa de regulação empregada pelo POSL. Sua escolha não parece aleatória, ela repete o verso "África, onde tudo começou", ou o reformula, "África, quando tudo começou". O verso faz referência ao fato de o continente africano ser considerado o berço das civilizações, a canção reitera a constatação científica de que a humanidade teve sua origem na África, bem como as inúmeras descobertas tecnológicas que propiciaram a sobrevivência e expansão da espécie. É este o trecho eleito por Duda em sua resposta performática para o professor, que não busca expandi-la ou acolhê-la.

No âmbito escolar, em que a matriz fundamental de socialização é o livro, a escolha do videoclipe para apropriação de um rap implica uma quebra de expectativas, o que destoa das práticas de leitura usuais. Lahire (2017, p. 142) ao discutir as leituras populares e os modos de apropriação dos textos, indica que "tendemos particularmente a considerar que todo texto é suscetível a uma apropriação do tipo comentário de texto ou exegese”. A imposição de um modo canônico de lidar com os textos é confrontada pela apropriação performática de Duda, que sinaliza a inadequação da proposta do POSL frente ao evento de letramento que tem um videoclipe de rap como artefato a partir do qual devem atribuir sentido. O professor, inicialmente, pretendia organizar uma roda de conversa sobre assuntos da canção, a despeito da utilização de um texto multimodal na aula, cujos modos de recepção são familiares aos/ às alunos/as. $\mathrm{O}$ modo como Duda reage leva o POSL a mudar sua estratégia, por meio da referência ao verso reiterado por Duda:
POSL: onde tudo começou, peraí... porque que a MC Soffia fala assim onde tudo começou?

Monique: $(\mathrm{xxx})$ a África veio para cá antes ... no começo

POSL: porque a África veio para o Brasil

Monique: [e foi assim que o Brasil se criou

POSL: e o Brasil se criou, muito bem essa fala sua Monique... agora eu quero saber, Gustavo, não peraí, o Ivan cada vez pertinho, da, do, Ivan que que a MC Soffia fala, que palavra que ela se utiliza para falar da África?

Quando o POSL retoma o refrão proposto por Duda, repondo a partir dele uma nova pergunta (no turno 14) a interação ganha nova configuração. Monique se autosseleciona e responde ao POSL, posicionando-se também a partir do refrão selecionado por Duda. Sua resposta, no entanto, refere-se à Diáspora negra, emprega o termo África para referir-se aos africanos/as (a África veio para cá...), os termos antes e começo sugerem que a origem do Brasil advém desse deslocamento, o que impele a reflexão sobre a matriz africana do povo brasileiro. Seu posicionamento, diferente do de Duda, recebe apoio do POSL (turno 18), que retoma seus dizeres, por meio de paráfrase e o avalia positivamente (muito bem).

Em seguida, alguns/mas alunos/as autosselecionam-se e colaboram na retomada de conteúdos da canção e na construção de uma identidade positiva sobre africanos/as e afrobrasileiros/as:

POSL: Então... sobre a África o que que ela fala? Monique: Ela fala sobre uma rainha... sei lá. POSL: O::pa... pera só um pouquinho Duda $(\mathrm{xxx})$ Duda ... eu não, Duda eu não vou falar mais (xxx) se você não participar ... calma ... oh... a Monique fez uma observação

Monique: ela falou que ela fala de uma gue .... de uma rainha guerreira $(\mathrm{xxx})$ que era igual a ela.

POSL: oh, Duda ó... a Monique falou que a MC Soffia fala que tem na gue / rainha

Monique: [guerreira, que ela queria ser igual a ela. POSL: [que ela queria ser igual a rainha guerreira Duda: professor eu (xxx) falar uma coisa... pro deixa eu só te falar uma coisa... a Monique ela é igualzinha a MC Soffia... só falta o lacinho no cabelo (xxx) POSL: você sabe ((dirige-se à Monique)) cantar também? depois eu quero ver você cantando $(++)$ oh... é ... então vamo lá, tem três coisas, tem duas coisas que a 
MC Soffia falou sobre a África... Cristiano esses cards aí? ((jogo de cartas que está mãos do menino))... o peraí, então vai acompanha comigo... onde tudo começou e a.

Duda: Á::fri::ca ((cantando)).

POSL: você ((Duda)) escolheu essa parte da música, a Monique ajudou a explicar a sua escolha que o Brasil começa com os a / a os africanos a África vem para o Brasil. Segunda coisa, a Monique reparou que a MC Soffia fala que tem uma ... prin/ rainha guerreira que ela queria ser igual... eu quero mais alguma coisa desse lado aqui

Gustavo: o direito dos negros

POSL: direito? qual parte da música que tem o direito dos negros?

Gustavo: onde tudo começou, aí que eles eram escravizados

Cris: é porque o Rodrigo nunca respeita o direito dos negros.

POSL: então... olha só onde tudo começou, que os negros eram escravizados, então isso tá falando sobre

Ivan: [oh pro... eu num sei se tem a ver com a África mas eu ouvi ela ((MC Soffia)) também falando do cabelo dela achatado ... num sei o que

POSL: não, ela falou.

Monique: [o nariz achatado

POSL: oh... eu estou com a letra da música, ela fala assim

Mariana: [nariz achatado

POSL: oh...Ivan, pra você Ivan o "menina do cabelo Black, nariz achatado, na periferia eu mando meu recado”... qual que é o recado que a MC Soffia tá mandando?

Duda: ela manda que se respeite os negros.

POSL: PE::ra só um pouquinho, o Duda senta ali o... ou senta aqui o... o ... peraí tem mais uma coisa ... o três coisas que.

Giovanna: oh.. professor, ela quer falar

POSL: oh... pe::ra só um... a Mariana o.

Mariana: oh... nariz da minha cachorra é achatado

POSL: o nariz da sua cachorra é achatado? .... pera só

um pouquinho ... coitado, e quando ele fica resfriado?

Se o nariz dele é.

Mariana: [ela.

POSL: ela?

Als: oh professor ... pro, pro, pro, aí conserta aí.

POSL: pera só um pouquinho, Ivan, ó volta comigo aqui.

Monique: Também tem uma parte que ela fala Cleópatra de um jeito $(\mathrm{xxx})$.

POSL: oh... TRÊS coisas que vocês... NA verDAde foi... a Monique... a Duda... e o Ivan... a Duda... onde tudo começou... a Monique... princesa/a rainha guerreira que a MC Soffia quer ser igual ... e o Ivan... eh:... do cabelo black e do nariz achatado... três coisas... eu estou com a letra... da música aqui oh... vou ler pra vocês a letra...

Duda: África, onde tudo começou: ((dirige-se ao centro do círculo e canta e dança para o professor))

Nos turnos 22-27, Monique colabora, mencionando uma das personagens da história africana citada na canção em resposta ao professor: uma rainha e guerreira africana. Seu enunciado contrasta com a representação hegemônica de princesas e rainhas no universo infanto-juvenil, geralmente brancas de origem europeia. Monique reacentua ainda a posição do eu da canção que se encontra nos versos "nascida de Angola, Guerreira Nzinga representou/quando crescer quero chegar onde ela chegou". Ela reapropria-se desses versos e enfatiza a identificação que faz entre a cantora (MC Soffia, menina negra e rapper) e a guerreira: "la falou que ela fala de uma gue .... de uma rainha guerreira (xxx) que era igual a ela". Ainda que desconheça a personagem histórica, reconhecida por sua resistência heroica contra os portugueses e comerciantes de escravos, a aluna percebe sua relevância, possivelmente pelo modo como é referida na canção. A retomada desse trecho, por meio da reformulação da aluna, denota o movimento de ampliação em andamento sobre as representações iniciais sobre africanos/as. Outra rainha que será citada ao final da sequência por Monique é Cleópatra, outra personagem também mencionada na canção.

Outro dado fundamental no processo de mediação de identidades ocorre entre os turnos 27 e 29. Após a identificação entre a cantora e guerreira Nzinga, Duda age novamente no sentido de sustentar uma identidade positiva em relação aos/às negros/as, comparando a colega Monique à cantora: "(...) a Monique ela é igualzinha a MC Soffia, só falta o lacinho no cabelo". Ainda que seu enunciado não se atenha diretamente à letra da canção, objeto da conversa, ela associa a colega à rapper. Essa turma demonstra uma grande admiração pela MC Soffia. Portanto, tal comparação entre a colega negra e a rapper representa uma percepção muito positiva, o que confirma seu comportamento 
assertivo acerca da identidade negra, já sinalizado no evento 1 .

Após a retomada das contribuições de Duda e Monique na roda pelo PosL, Gustavo responde à solicitação do professor de apresentar outras contribuições a respeito da letra da canção. O aluno se autosseleciona (turno 32) e diz: "o direito dos negros". Na sequência, o professor questiona sua contribuição, colocando outra pergunta: "direito? Qual parte da música que tem o direito dos negros?” A contribuição de Gustavo resulta de uma inferência e não de uma retomada explícita de versos ou trechos da canção, o que é esclarecido por sua resposta no turno 34: "onde tudo começou, ai que eles eram escravizados". Em oposição à condição de escravizados reafirma os direitos dos negros. Outro aluno, Cris, aproveita-se da fala de Gustavo, e trata do desrespeito em relação aos negros, denunciando um colega: "é porque o Rodrigo nunca respeita o direito dos negros", não resultando numa retomada pelo professor sobre atitudes antirracistas ou de respeito aos/às negros/as. Duda, posteriormente, traz outra inferência em relação ao tema posto na roda por Gustavo e Cris, quando o POSL pergunta sobre o recado dado na canção (... qual que é o recado que a MC Soffia tá mandando), a menina responde: "ela manda que se respeite os negros". Na roda, esses enunciados não são motes para expansóes, novas perguntas e aprofundamento pelo professor. Vale destacar ainda que Cris e Gustavo ainda não haviam participado da conversa, mas não estavam alheios à interação, já que nesse momento contribuem de modo bastante profícuo e propõem novos temas.

Nos turnos 37-50, é tematizada a caracterização física de pessoas negras por meio da retomada de um trecho da canção por Ivan, que adere à proposta do POSL e, em tom de dúvida, propóe "cabelo achatado". O professor o corrige, lendo em voz alta os versos do rap, mas sem solicitar que expanda sua contribuição, por meio da justificativa de sua escolha. Maria, outra aluna que toma a palavra na roda pela primeira vez, compara o nariz achatado citado da canção ao de seu animal de estimação, mas também não se discute os efeitos dessa comparação, produzida em tom de brincadeira, tampouco o que a canção coloca em foco: as representações estereotipadas em relação às características físicas dos/as negros/as e o modo como o eu da canção menciona essas características, reafirmando positivamente sua identidade como negra: menina com cabelo black e nariz achatado capaz de mandar seu recado para as periferias.

\section{Considerações finais}

Apesar de passados 15 anos da implementação de dispositivos legais visando à Educação das Relações Étnico-Raciais na Educação Básica, os dados em tela acenam avanços tímidos. Como detectado por Gomes e Jesus (2013), de um lado, é preciso reconhecer que há práticas nessa escola que merecem ser comemoradas, como o agenciamento de um projeto encampado pelo conjunto da instituição em torno do tema da diversidade étnico-racial, articulado ao seu Plano Anual de Ação, denotando sua sustentabilidade e enraizamento, bem como a organização de atividades que propiciam aos/às alunos/as ampliarem seus conhecimentos e reposicionarem-se em relação ao continente africano e à história de africanos/as e afrobrasileiros/as. De outro, tais propostas não escapam às tensões e conflitos, relativos à instituição onde são produzidos e à formação docente para o tratamento dessa temática. Parte dessas tensões e conflitos deriva da finalidade didática dos eventos, pela premência de desenvolver uma agenda preestabelecida a respeito do tema e dos assuntos visados pelo professor, e da forma escritural predominante e caráter propedêutico dos eventos de letramento escolar, especificamente, no tratamento dos textos e sua apropriação. Outra parte significativa advém da abordagem da temática, de conhecimentos e de atitudes bem como o papel da educação escolar na superação de discursos racistas e imagens preconceituosas e depreciativas sobre africanos/as e afro-brasileiros/ as, sedimentadas e largamente veiculadas em nossa sociedade. Abordagens para as quais nem sempre 
os profissionais da educação encontram-se formados e em condições de enfrentá-las.

Como se apresentou na análise, a dinâmica discursiva desenvolvida nesses eventos de letramento configura-se, pelos efeitos advindos tanto da recepção do videoclipe e do rap quanto da apropriação de seu conteúdo temático por meio da conversa entre pares, como oportunidades para alunos/as reverem e alçarem novos posicionamentos, para disputarem outros sentidos sobre pessoas negras e seus direitos, para ampliar conhecimentos e refletirem sobre comportamentos e atitudes. Há um jogo de forças tenso na mediação do processo de construção de identidades nos três eventos. Forças que atuam no sentido da restrição, quando se coloca em relevo certos objetivos didáticos e se tenta controlar significados e comportamentos dos/as alunos/as, por meio da não expansão ou recusa de seus enunciados na interação. Ou, alternativamente, forças que atuam no sentido de acomodação, acolhimento e valorização das proposições inusitadas dos/as alunos/as e extremamente produtivas quando se quer tematizar a Educação para as Relações Étnico-Raciais na escolarização básica.

Também se vislumbra uma disputa de posições dos/as alunos/as que resistem e contestam certas representações em posição hegemônica, agindo para a desconstrução de visões preconceituosas, naturalizadas, e para o estabelecimento de novas relações interpessoais, reforçando elos entre eles/ as e reorganizando valores e conhecimentos. Essas disputas tornam-se palpáveis nas participações de Duda, Monique, Ivan e Gustavo. Em Duda, no comportamento assertivo frente às pessoas negras, colocando em cena atributos positivos e reacentuando trechos da canção, mesmo diante do silêncio e da recusa de suas participações, inesperadas pelo professor. Em Monique, quando retoma e valora positivamente temas da canção, aderindo às propostas do professor e realçando o legado cultural africano. Em Ivan, quando destaca aspectos físicos do corpo negro, o que poderia colocar sob suspeição às relações que se fazem em nossa sociedade sobre a estética corporal de negros e negras. E ainda, na inferência de Gustavo, tematizando os direitos dos/as negros/as a partir do conteúdo temático da canção e da problemática reacentuada por Rodrigo.

Por fim, os resultados indicam que esses eventos de letramento contribuíram para desestigmatizar e rever estereótipos frente ao continente africano e aos/às negros/as africanos/as e brasileiros/as, assim como para produzir novos posicionamentos frente a essas construções sociais e observar os modos como aprendemos a ser o que somos no interior da escola.

\section{Referências}

Bakhtin, M. ([1975] 1993). Questões de literatura e de estética: a teoria do romance. São Paulo: UNESP; Hucitec.

Barton, D. e Hamilton, M. (2004). La literacidad entendida como práctica social. Em V.Zavala,M. Niño-Murcia, e P. Ames, Escritura y sociedad: nuevas perspectivas teóricas y etnográficas. Lima: Red para el Desarrollo de las Ciencias Sociales en el Perú.

Brasil. (2003). Lei N. ${ }^{\circ}$ 10.639, de 09/01/2003. Brasília: Diário Oficial da União, Poder Legislativo, $10 / 01 / 2003$.

Brasil, MEc, Secretaria Especial de Políticas de Promoção da Igualdade Racial. (2004a). Diretrizes curriculares nacionais para educação das relaçôes étnico-raciais e para o ensino de história e cultura afrobrasileira e africana. Brasília: MEC-SEPPIR.

Brasil. (2004b). Resolução N.o 01, de 17/06/2004. Brasília: Diário Oficial da União, Poder Legislativo, 22/06/2004.

Bunzen, C. S. (2009). Dinâmicas discursivas na aula de português: os usos do livro didático e projeto didáticos autorais. Tese de doutorado. Universidade Estadual de Campinas. Instituto de Estudos da Linguagem, Campinas.

Bunzen, C. S. (2010). Os significados do letramento escolar como uma prática sociocultural. Em C. Vóvio, L. Sito, y P. de Grande, Letramentos: rupturas, deslocamentos e repercussóes de pesquisa em Linguistica aplicada (pp. 99-120). Campinas: Mercado de Letras.

Cuche, D. (2002). A noção de cultura nas ciências sociais. Bauru: EDUSC. 
Firmino. E. M. A. (2015). Sala de leitura na rede municipal de São Paulo: reflexões sobre eventos e práticas de letramento com uma turma de $4^{\circ}$ ano (dissertação de mestrado). Universidade Federal de São Paulo, Escola de Filosofia, Letras e Ciências Humanas, Guarulhos.

Fleuri, R. M. (2003). Intercultura e educação. Revista Brasileira de Educação, 23, 16-35. https://doi.org/10.1590/ S1413-24782003000200003

Garcez,P.eLopes, M.F.R.(2017).Oportunidades de aprendizagem na nova ordem comunicativa da fala-em-interação de sala de aula contemporânea: língua espanhola no Ensino Médio. Trab. Ling. Aplic., 1(56), 65-75. https://doi.org/10.1590/010318135160183301

Gomes, N. L. (2005). Alguns termos e conceitos presentes no debate sobre relações raciais no Brasil: uma breve discussão. Em Brasil. Educação anti-racista: caminhos abertos pela Lei federal N. ${ }^{\circ} 10.639 / 03$ (pp.39-62). Brasília: MEC-Secretaria de Educação Continuada e Alfabetização e Diversidade.

Gomes, N. L. (2012). Práticas pedagógicas de trabalho com relações étnico-raciais na escola na perspectiva da Lei 10.639/03. Brasília: MEC-UNEsco.

Gomes, N. L., e Jesus, R. E de. (2013). As práticas pedagógicas de trabalho com relações étnico-raciais na escola na perspectiva de Lei 10.639/2003: desafios para a política educacional e indagações para a pesquisa. Educar em Revista, 29(47), 19-33. https://doi. org/10.1590/S0104-40602013000100003

Hall, S. (2000). Quem precisa de identidade? Em T. T. da Silva, Identidade e diferença: a perspectiva dos Estudos Culturais (pp. 133-178). Rio de Janeiro: Vozes.

Hamilton, M. (2000). Expanding the new literacy studies: using photographs to explore literacy as social practice. Em D. Barton, M. Hamilton, e R. Ivanic (Orgs.), Situated literacies (pp. 16-34). Londres: Routledge.

Heath, S. B. (1989). Ways with words. Nova Iorke: Cambridge University Press.

Holland, D.; Lachicotte Jr., W.; Skinner, D., e Cain, C. (1998). Identity and agency in cultural worlds. Cambridge, Mass: Harvard University Press.

Instituto Brasileiro de Geografia e Estatística - IBGE(2016). PNAD Contínua. Disponível em: https:// ww2.ibge.gov.br/home/estatistica/indicadores/trabalhoerendimento/pnad continua/default.shtm.

INEP. (2015). Escala de desempenho de Língua Portuguesa na Prova Brasil e SAEB. Disponível em: < http:// portal.inep.gov.br/web/saeb/resultados-2015>.
Kleiman, A. B. (1995). Os significados do letramento: uma nova perspectiva sobre a prática social da escrita. Campinas: Mercado das Letras.

Kleiman, A. B. (1998). A construção de identidades em sala de aula: um enfoque interacional. Em I. Signorini (Org.), Linguagem e identidade: elementos para uma discussão no campo aplicado (pp. 115-138). Campinas: Mercado de Letras; São Paulo: FApesp.

Kleiman, A. B. e Sito, L. R. S. (2016). Multiletramentos, interdições e marginalidades. Em A. B. Kleiman e J. A. Assis (Orgs.), Significados e ressignificações do letramento: desdobramentos de uma perspectiva sociocultural sobre a escrita (pp. 169-198). Campinas: Mercado de Letras.

Lahire, B. (2004). Sucesso escolar nos meios populares: as razões do improvável. São Paulo: Ática.

Lahire, B. (2017). Leituras populares: modos de apropriação de texto. Em R. Visser e L. Junqueira, (Orgs.), Dossiê Bernard Lahire. Belo Horizonte: Editora UFMG.

Macedo, M. do S. A. N. (2005). Interaçôes nas práticas de letramento: o uso do livro didático e da metodologia de projetos. São Paulo: Martins Fontes.

Marinho, M. (2010). Letramento: a criação de um neologismo e a construção de um conceito. Em M. Marinho e G. T. Carvalho (Orgs.), Cultura escrita e letramento (pp. 68-100). Belo Horizonte: Editora UFMG.

Matêncio, M. de L. M. (2001). Estudo da língua falada na aula de lingua materna. Campinas: Mercado de Letras.

Matêncio, M. de L. M. (2009). Estudos do letramento e formação de professores: retomadas, deslocamentos e impactos. Caleidoscópio, 7(1), 5-10.

Moita-Lopes, L. P. da. (2002). Identidades fragmentadas: a construção discursiva de raça, gênero e sexualidade em sala de aula. Campinas: Mercado das Letras.

Moita-Lopes, L. P. da (2013). O português no século XXI: cenário geopolitico e sociolinguístico. São Paulo: Parábola Editorial.

Mozdzenski, L. P. (2012). O ethos e o pathos em videoclipes femininos: construindo identidades, encenando emoçôes. Tese de doutorado. Universidade Federal de Pernambuco. Centro de Artes e Comunicação, Recife.

Munanga, K. (2008). Rediscutindo a mestiçagem no Brasil: identidade nacional versus identidade negra. Belo Horizonte: Autêntica Editora.

Polido-Silva, N. E. da. (2012). Sala de leitura da rede municipal de ensino de São Paulo: caminhos possiveis para 
redimensionar seu funcionamento. Tese de doutorado em Educação. Faculdade de Educação da Universidade de São Paulo, São Paulo.

Rojo, R. H. R. (2010). Letramentos escolares: coletâneas de textos nos livros didáticos de língua portuguesa. Perspectiva, 28(2), 433-465.

Rojo, R. H. R. (2013).Escol@conectada: os multiletramentos e as TICs. São Paulo: Parábola Editorial.

São Paulo (Cidade). (2015). Portaria N. ${ }^{\circ}$ 7.655, de 17/12/2015. Diário Oficial de São Paulo.

São Paulo (Cidade). (2018). Sala de Leitura: 45 anos formando leitores. São Paulo : Secretaria Municipal de Educação (SME0; Coordenadoria Pedagógica (COPED).

SEADE. Índice Paulista de Vulnerabilidade Social. Disponível em: http://www.seade.gov.br/indice-paulista-de-vulnerabilidade-social-ipvs-versao-2010

Sito, L. R. S. (2010). Ali tá a palavra deles: um estudo sobre práticas de letramento em uma comunidade quilombola do litoral do estado do Rio Grande do Sul. Dissertação de mestrado. Universidade Estadual de Campinas, Instituto de Estudos da Linguagem, Campinas.

Sito, L. R. S. (2016). Escritas afirmativas: estratégias criativas para subverter a colonialidade em trajetórias de letramento acadêmico. Tese de doutorado. Universidade Estadual de Campinas, Instituto de Estudos da Linguagem, Campinas.

Soares, M. (2010). Práticas de letramento e implicações para a pesquisa e para políticas de alfabetização e letramento. Em M. Marinho e G. T. Carvalho (Orgs.), Cultura escrita e letramento (pp. 54-67). Belo Horizonte: Editora UFMG.
Souza, A. L. S. (2009). Letramentos de reexistência: culturas e identidades no movimento Hip Hop. Tese de doutorado. Universidade Estadual de Campinas, Instituto de Estudos da Linguagem, Campinas.

Street, J. C. e Street, B. V. (2004). La escolarización de la literacidad. Em V. Zavala, et al. (Eds.), Escritura y sociedad: nuevas perspectivas teóricas e etnográficas (pp. 181-201). Lima: Red para el Desarolllo de las Ciencias Sociales en el Perú.

Street, B. (2014). Letramentos sociais: abordagens criticas do letramento no desenvolvimento, na etnografia e na educação. São Paulo: Parábola Editorial.

Viana, C. A. D., Sito, L. R. S., Valsechi, M. C. e Pereira, S. L. M. (2016). Do letramento aos letramentos: desafios na aproximação entre letramento acadêmico e letramento do professor. Em A. B. Kleimane J. A. Assis, J. A. (Orgs.), Significados e ressignificações do letramento: desdobramentos de uma perspectiva sociocultural sobre a escrita (pp. 27-62). Campinas : Mercado de Letras.

Volochinov, V. (2017). Marxismo e filosofia da linguagem: problemas fundamentais do método sociológico na ciência da linguagem. São Paulo: Editora 34.

Vóvio, C. L., e Souza, A. L. S. (2005). Desafios metodológicos em pesquisas sobre letramento. Em A. Kleiman, e M. de L. M. Matencio, (Orgs.), Letramento e formação do professor: práticas discursivas, representaçôes e construção do saber (pp. 41-64). Campinas: Mercado de Letras.

Vóvio, C. L., e De Grande, P. B. (2010). O que dizem as educadoras sobre si: construções identitárias e formação docente. Em C. L. Vóvio, L. S. Sito, e P. B. de Grande (Orgs), Letramentos: rupturas, deslocamentos e repercussóes de pesquisas em Linguistica Aplicada (pp. 51-70). Campinas: Mercado de Letras.

How to reference this article: Vóvio, C. L. e Firmino, E. A. (2019). A construção de identidades étnico-racial em eventos de letramento numa escola pública municipal de São Paulo. Íkala, Revista de Lenguaje y Cultura, 24(2), 307-327. Dor: A10.17533/udea.ikala.v24n02a07 